\title{
THE LIBRARY IN A RESEARCH ORGANISATION
}

Conferences of professional librarians are rather stuffy affairs-dry as the dust that accumulates on their books. There are delightful exceptions. At a discussion on the planning and equipment of special libraries organised by ASLIB (Association of Special Libraries and Information Bureaux) in London on April 6th the writer of this note was intrigued by a "running commentary, based on his own experience," vividly and humorously presented by B. Fullman, B.Sc., A.R.I.C., Information Officer, British Non-Ferrous Metal Research Association, on "The Planning and Equipment of Libraries in Research Organisations and Industrial Concerns."

A library in a research organisation, particularly where laboratory or field work of a practical nature is carried out, is essentially an information centre. Since human beings are stimulated by surroundings having architectural grace and beauty, it should be as pleasant and attractive as possible. Formality should be cut down to a minimum, and smoking should certainly be allowed. Describing the various functions of the library: repository of the organisation's literature, published and internal; reading-room; lending library; centre for receipt of enquiries; dissemination of information; distribution of reports,

Mr. Fullman insisted on its easy accessibility, frequent visits by the users being to the advantage of all concerned. In a small organisation this is not difficult, but in a large one, perhaps involving many buildings and long distances, the story is very different. 'The speaker next dealt with various nuisances encountered in a library. People vary a good deal in the amount of noise which they can tolerate. The French author Marcel Proust worked in a special noise-proof room. On the other hand, there are special libraries situated on main London roads! Even where readers seem to be quite comfortable in such cases, they must at some level of consciousness be devoting a certain amount of energy to counteracting the effects of the noise. A library should not be situated under a chemical laboratory where large quantities of liquids run to waste. For a laboratory worker who really gives his mind to it can defeat the plans of any architect!

In the main library it is difficult, even unfair, to impose a silence rule, for readers sometimes like to argue their difficulties out over the literature. Special rooms are conveniently reserved for abstracting, translating, cataloguing, reading microfilms, and for telephone conversations.

The reader of the paper stressed the desirability of open access. Regular users of libraries like to browse about by themselves, such an arrangement incidentally taking the strain off the librarian. (According to the Librarian of Liverpool University, open access, though indispensable to the steady research worker and useful for an occasional survey of materials, has its disadvantages. Looking in vain for a book that someone else has borrowed far from having a beneficial effect in introducing you to other books you do not want, is a wanton waste of time and a negation of exact scholarship.)

The most useful arrangement for housing current journals is some racking system, in which the whole year's issues are kept together, the current one at the top. Pamphlets are stored in flap-lidded boxes with a short leather strap to pull them off the shelves. In view of the great shortage of materials, Mr. Fullman was wondering if some use might not be made of aluminium or its light alloys for shelving and furniture.

The discussion tackled among others the topic of microfilms. According to one speaker it had been proved in the U.S.A. that the cost of microfilming was not higher than that of packing books, sending them to various recipients and watching for their return. Unfortunately, many people are still prejudiced against reading microfilms, and prejudices are tough customers to kill. A refreshing and worthwhile conference.

W. R. B. 